\title{
ASSESSMENT ON HYDROTHERMAL PARTICLE CHEMISTRY FROM A SHALLOW VENTING SYSTEM OFFSHORE KOS, AEGEAN SEA
}

\author{
Megalovasilis P. \\ University of Patras, Department of Geology,26504,Patras, Greece,pmegal@upatras.gr
}

\begin{abstract}
Shallow submarine hydrothermal vents along Hellenic Volcanic Arc transfer significant quantities of particles enriched in basic metals. Fluids collected by scuba diving from two shallow hydrothermal venting areas on Kos Island in the Aegean Sea in East Mediterranean. Samples were filtrated and membrane filters leached with a mixture of acids. Chemical analysis performed in suspended particles for $\mathrm{Fe}, \mathrm{Mn}, \mathrm{Cu}, \mathrm{Pb}, \mathrm{Cd}, \mathrm{Ca}$, $\mathrm{Ba}, \mathrm{Sr}, \mathrm{Li}, \mathrm{Al}$ and Si. The suspended particulate matter (SPM) flux varied from 0.93 to $8.64 \mathrm{mg} / \mathrm{l}$ and between 0.21 and $20.94 \mathrm{mg} / \mathrm{l}$ in two sites. Metal/Al ratios also vary significantly within a short distance. The $\mathrm{pH}$ of hydrothermal waters was from 5.50 to 5.95 in Kephalos Bay and from 6.09 to 6.53 in Bros Thermi suggesting gases $\mathrm{CO}_{2}$ and $\mathrm{H}_{2} \mathrm{~S}$ may control $\mathrm{pH}$ values. Particles were dominated by $\mathrm{Fe}$, Ca, Si and Al and strongly enriched in $\mathrm{Mn}, \mathrm{Cu}, \mathrm{Pb}$ and $\mathrm{Ba}$. Three geochemical groups were identified being associated with distinct hydrothermal processes concerning sulphide minerals, carbonate substrate and deeper Al-Silicate rock basement.
\end{abstract}

Keywords: particulate matter, basic metals, vents, Hellenic Volcanic Arc.

\section{Пврі́ $\eta \psi \eta$}

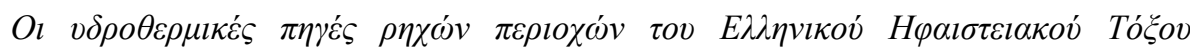

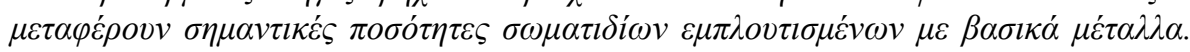

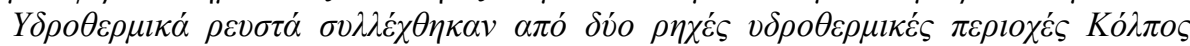

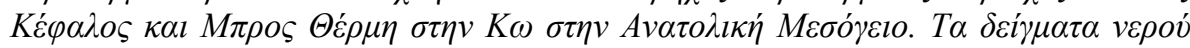

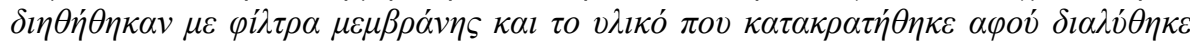

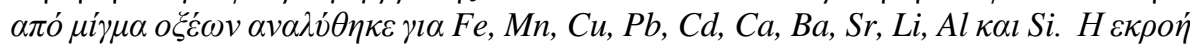

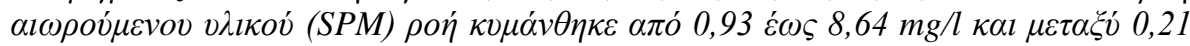

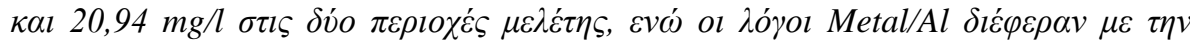

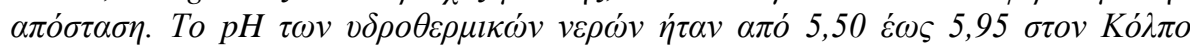

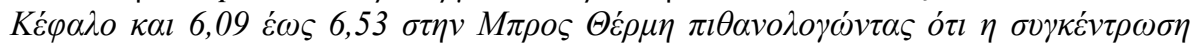

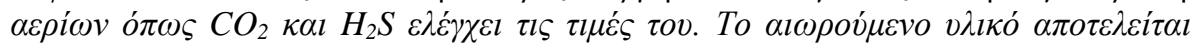

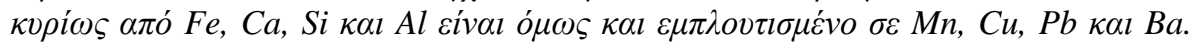

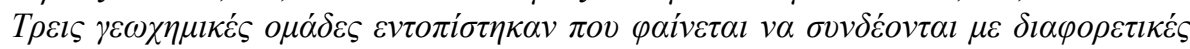

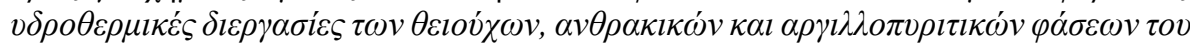

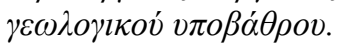

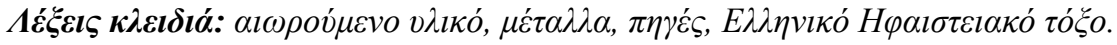




\section{Introduction}

The seafloor hydrothermal vent systems influence marine chemistry in every timescale and in large extent (Von Damm, 1990; Parson et al., 1995; Von Damm, 2001). The spatial evolution of magmatic-hydrothermal systems very often presents great extent of several kilometres into the crust and the formation of hydrothermal plumes on sea column (Humphris et al., 1995; Lupton, 1995; Edmonds and German, 2004). The hydrothermal fluid phase such as gases, water, solutes and particulate matter. Particulate matter indeed is an important constituent of hydrothermal fluids and actually it represents sedimentary material in early stage of formation (Whittield and Turner, 1987). The compositional variability of suspended particulate matter (SPM) depends upon a number of factors such and the nature of chemical reactions taking place in the substrate the prevailing physicochemical and oceanographic conditions, the amount of dissolved oxygen, other gas content and the rate of mixing of hydrothermal fluids with seawater (Von Damm et al., 1985). Particulate Fe and Mn was found in unusually high concentrations in South Aegean Sea, comparing to other straits of Mediterranean and their origin was attributed to hydrothermal sources (Balopoulos et al., 1999). Furthermore, particulate matter distribution in Aegean Sea seawater is influenced mainly by three factors such as the proximity to the initial sources, the water circulation patterns prevailing and the topography of sea-bottom, while resuspension phenomena affect sediment depositional geochemistry of surface sediments (Karageorgis and Anagnostou, 2001). Moreover, the shallow submarine hydrothermal venting related to the Hellenic Volcanic Arc and its influence on seabed and seawater chemistry has been well investigated (Dando et al., 2000; Price et al., 2013; Yücel et al., 2013), while controls local marine sediment geochemistry have been also attributed (Megalovasilis, 2014, Megalovasilis and Godelitsas, 2015). There are few studies on particle emission in submarine hydrothermal areas in Aegean (Varnavas et al., 1998; Varnavas et al., 2000; Megalovasilis, 2007; Megalovasilis, 2015a; Megalovasilis, 2015b). In this work, statistical data are presented and an assessment on elemental interrelationships between hydrothermal particulates is attempted. Such a research is important because it provides further information on the geochemical influence of hydrothermal fluids along the Hellenic island volcanic arc.

\section{Materials and Methods}

Sampling was carried out in Kephalos Bay and Bros Thermi. Interactions between hydrothermal fluids and oxygenated seawater result in various precipitates settling to the sea bottom around the venting seeps influence strongly local sediment geochemistry (Megalovasilis and Godelitsas, 2015). Fe oxides and hydroxides are observed both in Kephalos Bay and Bros Thermi. A variety from brown-red Fe oxides to yellowish Sulphur and metal-sulphides phases together with white silica - bacterial mat are observed around the seeps but in lesser extent than those recognised in Milos (Dando et al., 1998; Godelitsas et al., 2015). Samples obtained by scuba diving using fluid samplers consisted of two double plastic bags connected by a Y-shaped selectable plastic connector to a plastic funnel, applied on the top of the venting outlet. All parts were laboratory ultra pure acid cleaned. The first bag was used for collecting primary wastes (sand and seawater) while second bag collection was timed. The volume of gas+water and only water was measured with the Archimedes method of water displacement (Dando et al., 1995). Water samples were transferred in glass bottles. The $\mathrm{H}_{2} \mathrm{~S}$ was detected in all samples by its characteristic smell. The hydrothermal waters were filtered in the field setup laboratory using a vacuum pump system and with the aid of Millipore Sterifil Aseptic System Holder and Millipore $0.45 \mu \mathrm{m}$ pre-weighted membrane filters while both the ending tube and the top funnel were sealed with plastic covers (Loring and Rantala, 1992). After filtration the sample-filters were then dried in an evacuated desiccator over silica gel and stored in acid-cleaned individual Petri slides. After weighing, the suspended particulate matter on the membrane filters was subjected to chemical leaching (Landing and Lewis, 1991), with the addition of $20 \mathrm{ml}$ of extra high purity $2 \mathrm{M} \mathrm{HCl}-1 \mathrm{M} \mathrm{HNO}_{3}$ mixture, samples left for 4 hours at room temperature. Flasks were put afterwards on a hot plate at $65^{\circ} \mathrm{C}$ near dryness and after they were cool, $5 \mathrm{ml}$ of mixture $0.5 \mathrm{M} \mathrm{HCl}-0.1 \mathrm{M} \mathrm{HNO}_{3}$ were added. All reagents and stock standards for AAS were of extra high purity commercially obtained (Merck), while 3-distilled water 
used for preparation of all reagents and working standards, and for rinsing all glassware which previously had been immersed for 2 days in $10 \% \mathrm{wt} \mathrm{HNO}_{3}$. Aliquots of the samples were analysed for $\mathrm{Fe}, \mathrm{Mn}, \mathrm{Cu}, \mathrm{Pb}, \mathrm{Cd}, \mathrm{Ca}, \mathrm{Ba}, \mathrm{Sr}, \mathrm{Li}, \mathrm{Al}$ and $\mathrm{Si}$, applying Atomic Absorption Spectrometry with Graphite furnace technique (GFFAS) using Perkin Elmer 2100 AAS and 701HGA Graphite Furnace. The operational parameters applied were of these from manufacturer and modified depending on the element (Loring and Rantala, 1992). Accuracy checked with the sensitivity check standards found better than $\pm 5 \%$ while analytical precision was checked with replicate analyses and found varied from \pm 5 to $\pm 10 \%$.

\subsection{Geological setting}

The Hellenic volcanic arc (HVA) in east Mediterranean region, is part of the pre-Alpine to Quaternary continental crust of the Hellenic subduction zone (Pichon and Angelier, 1979) and is a rather young (5 $\mathrm{Ma})$ volcanic arc in the pre-Alpine to Quaternary continental crust of the Hellenic subduction zone ( $\mathrm{R}$ oyden and Papanikolaou, 2011). It is the result of northward subduction of the last remnant of the oceanic crust of the African plate beneath the southern edge of the active margin of the European plate (Pichon and Angelier, 1979). The volcanoes of the HVA occur onshore the peninsula of Methana, and offshore the islands of Poros in the west, Milos and Santorini in the centre, and on Nisyros and Kos in the east (Fig. 1). Many submarine volcanoes have been discovered recently including Paphsanias near Methana, the volcanic domes to the east of Antimilos near Milos, and the Christiana domes and Kolumbo near Santorini (Nomikou et al., 2013). A great explosion occurred before $161 \mathrm{ka}$ between Nisyros and Kephalos Bay producing $>60 \mathrm{~km}^{3}$ of volcanic material which covered half of the island of Kos. Mainly the western part covered with a layer of ash and pumice of about 30 meters in thickness. This formation is unconformably overlying or concordant with older stratified sediment in west Kos basin of thickness more than $100 \mathrm{~m}$. Kos Plateau Tuff (KPT) eruption was the largest eruption in the Pliocene-Quaternary in Hellenic volcanic arc (Pe-Piper et al., 2005). Kos is controlled by WNW-ESE and NE-SW faults systems, which are related to extensional processes and volcanic activity during the Pleistocene and Pliocene (Papanikolaou and Lekkas, 1990; Lagios et al., 1998). The Kos-Nisyros volcanic center is a Plio-Pleistocene magmatic system which characterized by magmas with variable composition of basaltic andesite to high- $\mathrm{SiO}_{2}$ rhyolite, formed during last 3-4 Ma (Bachmann et al., 2012). Geothermal manifestations on the island are found in various locations such as the hot spring of cape Agios Fokas (Ruffa et al., 1999) in the NE part called Empros Thermes (Bros Thermi in modern Greek), where there is active flow of warm water into the beach of Thermes with temperature of $47{ }^{\circ} \mathrm{C}$ (Varnavas et al., 1998) and the hot spring of Agia Irini (Piso Thermes), which is easily accessible by boat, with fluid temperature of $45^{\circ} \mathrm{C}$. Also, there are other hot spring at Kokkinonero found southwest of the Asclepeion archaeological site where water is ferruginous (red in colour) and rich in carbon oxides $\left(\mathrm{CO}, \mathrm{CO}_{2}\right)$ with a temperature of $22.5^{\circ} \mathrm{C}$ (Hatzivasileiou, 2013). Finally there is the Volcano hot spring containing muddy mineral water and the hot spring of Kokkinonero nearby (Ruffa et al., 1999). A famous submarine hydrothermal site is the Paradise Beach on Kephalos Bay and together with Bros Thermi they gain a lot of attraction from tourists. Previous research on hydrothermal gas chemistry showed that springs onshore and offshore contain $\mathrm{CO}_{2}(93-99 \%), \mathrm{H}_{2} \mathrm{~S}$ $(<0.005 \%), \mathrm{H}_{2}(<0.001 \%), \mathrm{CH}_{4}(0.008-0.362 \%), \mathrm{N}_{2}(1.10-4.82 \%), \mathrm{O}_{2}$ and $\mathrm{Ar}(0.030-0.912 \%)$ (Minissale et al., 1997).

The Kos-Nisyros volcanic activity presents great variation with time the last $3 \mathrm{Ma}$ (Bachmann et al., 2012). Although recent and present times are not characterized by any volcanic activity, active onshore fumaroles and shallow submarine hydrothermal fields are found around Nisyros and Yali islands and along the southern coast of Kos (Varnavas and Cronan, 1991), particularly near shore in Kephalos Bay (Paradise bubble beach) in south-west and Bros Thermi in northeast (Megalovasilis and Godelitsas, 2015). At Bros Thermi, seawater moving downwards being modified by water-rock interactions and circulates with $\mathrm{Mg}$ and $\mathrm{K}$ losses, reaching $110^{\circ} \mathrm{C}$ close to sea bottom while meteoric water contribution has been found in other geothermal sites in Kos (Ruffa et al., 1999). Details on physiographic characteristics of submarine study areas (i.e bathymetry etc.), can be found in previous research (Megalovasilis and Godelitsas, 2015). 


\section{Results}

\subsection{Kephalos Bay}

The geochemical data obtained show a significant variability in all parameters (Table 1). The water flux varied from 60 to $122 \mathrm{l} / \mathrm{h}$ and the gas flux values varied from 2 to $126 \mathrm{l} / \mathrm{h}$ while the gas/water ratio found between 0.03 and 1.30 . The hydrothermal suspended particulate matter (SPM) varied from $0.93-8.64 \mathrm{mg} / \mathrm{l}$ with an average of $4.32 \mathrm{mg} / \mathrm{l}$. The $\mathrm{pH}$ in vent waters found between 5.50-5.95 and conductivity was $56.7-57.5 \mathrm{mS} / \mathrm{cm}$. Fe concentrations in SPM were from 8.7-87.2 $\mu \mathrm{g} / \mathrm{l}, \mathrm{Mn}$ $0.14-2.33 \mu \mathrm{g} / \mathrm{l}, \mathrm{Cu} 0.01-0.34 \mu \mathrm{g} / \mathrm{l}, \mathrm{Pb} 0.05-0.52 \mu \mathrm{g} / \mathrm{l}$, and $\mathrm{Cd}$ found only in few samples being $0.001-$ $0.015 \mu \mathrm{g} / \mathrm{l}$. Ca varied from 16.9 to $215 \mu \mathrm{g} / \mathrm{l}$, Ba from 0.16 to $1.46 \mu \mathrm{g} / \mathrm{l}$ and $\mathrm{Sr} 0.12-2.07 \mu \mathrm{g} / \mathrm{l}$. $\mathrm{Li}$ varied from 0.01-0.28 $\mu \mathrm{g} / \mathrm{l}, \mathrm{Al} 4.83-90.25 \mu \mathrm{g} / \mathrm{l}$ and $\mathrm{Si} 1.23-112.5 \mu \mathrm{g} / \mathrm{l}$. SPM concentrations are well correlated (correlation coefficient $0.70<\mathrm{r}<0.98$ ) with all elements except $\mathrm{Cu}, \mathrm{Cd}$ and $\mathrm{Si}$. Based on average values of hydrothermal water flux obtained and on the number of vents studied an estimation of annual fluxes can be deduced (i.e. water average discharge/h $\mathrm{x}$ hours of year $\mathrm{x}$ number of vents). Consequently annual flux of SPM also can be calculated based on annual water discharge. The annual hydrothermal water flux is estimated $819 \mathrm{~m}^{3} / \mathrm{y}$, the annual gas flux $636 \mathrm{~m}^{3} / \mathrm{y}$ and annual production of SPM to $24,749 \mathrm{~g} / \mathrm{y}$. Actual fluxes should be at least 2 orders of magnitude much more because the total number of observed hot spots is much higher than those studied. Many seeps are not even visible continuously, because gas effluence which gives the visual character of outflow is intermittent.

\subsection{Bros Thermi}

Significant variability is also observed in this submarine hydrothermal field. The water flux varied from 16.5 to $96 \mathrm{l} / \mathrm{h}$ and the gas flux values varied from 4.5 to $60 \mathrm{l} / \mathrm{h}$ while the gas/water ratio was between 0.18 and 1.14. The SPM flux varied from $0.21-20.94 \mathrm{mg} / \mathrm{l}$ with an average of $6.06 \mathrm{mg} / \mathrm{l}$.

The $\mathrm{pH}$ in vent waters found between 6.09-6.53. Fe concentrations in SPM were from 6.5-229 $\mu \mathrm{g} / \mathrm{l}$, Mn 0.05-2.17 $\mu \mathrm{g} / \mathrm{l}, \mathrm{Cu} 0.10-1.01 \mu \mathrm{g} / \mathrm{l}, \mathrm{Pb} 0.08-1.34 \mu \mathrm{g} / \mathrm{l}$, and $\mathrm{Cd}$ recorded in most samples being $0.001-0.038 \mu \mathrm{g} / \mathrm{l}$. Ca found between 14.6 and $182 \mu \mathrm{g} / \mathrm{l}$, Ba from 0.09 to $0.91 \mu \mathrm{g} / \mathrm{l}$ and $\mathrm{Sr} 0.13-1.19$ $\mu \mathrm{g} / \mathrm{l}$. Finally Li varied from 0.01-0.85 $\mu \mathrm{g} / \mathrm{l}$, Al 1.53-192 $\mu \mathrm{g} / \mathrm{l}$ and Si 0.56-105 $\mu \mathrm{g} / \mathrm{l}$. SPM concentrations are very well positively correlated $(0.70<\mathrm{r}<0.99)$ with all elements studied and moderate positively with $\mathrm{Cd}(\mathrm{r}=0.54)$. Analytical results are presented in Table 1 . On the basis of average values and the number of submarine hydrothermal vents studied, annual values can be estimated. Thus, the total hydrothermal water flux is estimated $418 \mathrm{~m}^{3} / \mathrm{y}$, gas flux $216 \mathrm{~m}^{3} / \mathrm{y}$ and for SPM 40,540 g/y. For similar reasons as in Kephalos Bay the actual outflow should be two orders of magnitude higher.

\subsection{Element to Al ratios}

To examine the origin of particulate metals from another view element/Al ratios of their concentrations in SPM were estimated (Table 2). Remarkably, differences on time and space compositional variability of SPM were observed. In Bros Thermi Vent B1 showing higher values for $\mathrm{Fe} / \mathrm{Al}, \mathrm{Cu} / \mathrm{Al}, \mathrm{Pb} / \mathrm{Al}, \mathrm{Cd} / \mathrm{Al}$ and $\mathrm{Ca} / \mathrm{Al}$ where $\mathrm{Kephalos}$ Bay vents are presenting elevated $\mathrm{Mn} / \mathrm{Al}$, $\mathrm{Ba} / \mathrm{Al}$ and $\mathrm{Si} / \mathrm{Al}$ ratios considering all analytical data obtained.

The present data strongly suggest that elements are concentrated in different phases in which they are held. The inter-element correlations of particulate elements imply not only a hydrothermal origin, for some particulates (e.g. Ba, Si) but also a biological affiliation of biogenic debris, or calcareous and siliceous tests. A further mineralogical investigation should be performed in order to clarify the above hypothesis. Notably the metal/Al varies significantly from vent to vent within a short distance, both in Kephalos Bay and in Bros Thermi. 


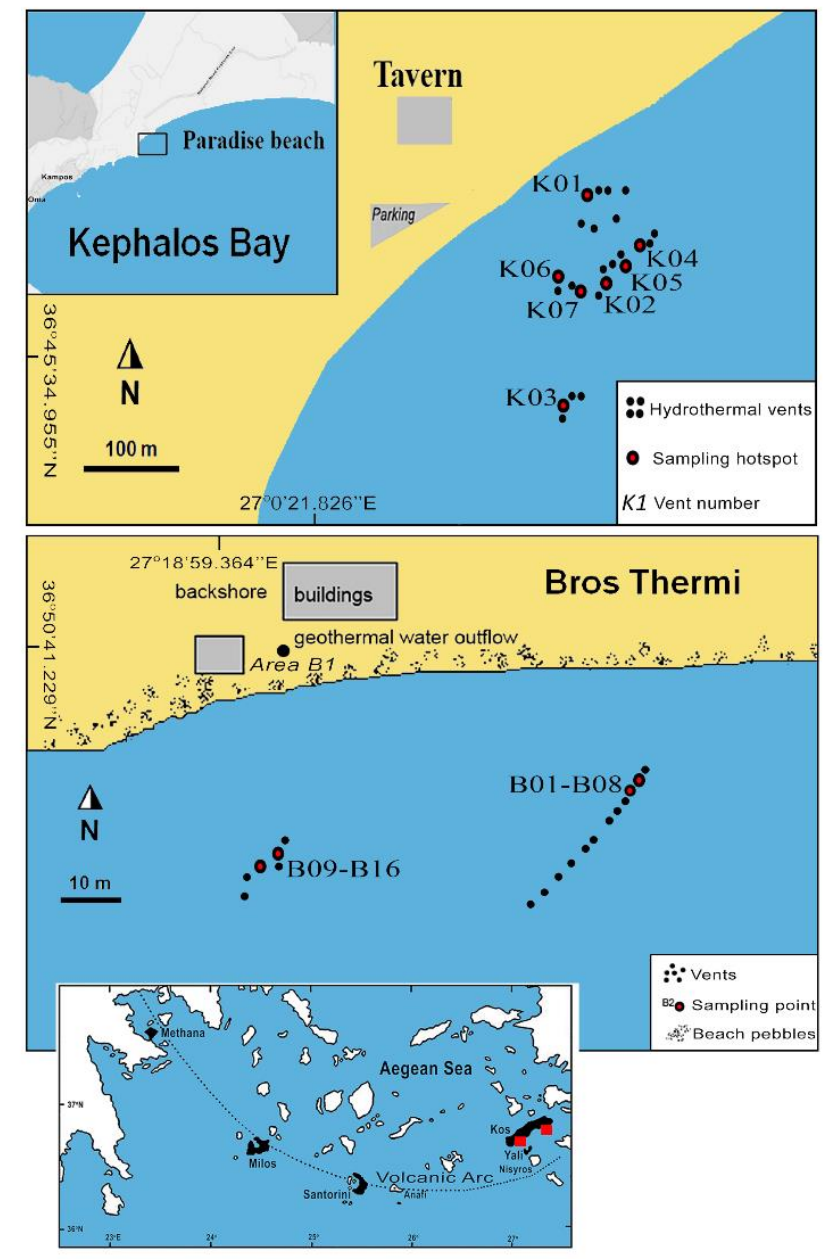

Figure 1 - Study area and sampling sites.

Although $\mathrm{Fe} / \mathrm{Al}$ and $\mathrm{Mn} / \mathrm{Al}$ follow different trends between the two hydrothermal fields, the $\mathrm{Cu} / \mathrm{Al}$, $\mathrm{Pb} / \mathrm{Al}$ and $\mathrm{Cd} / \mathrm{Al}$ are showing quite similar correlation indicating a possible common hydrothermal phase. Moreover, $\mathrm{Ca} / \mathrm{Al}, \mathrm{Ba} / \mathrm{Al}$ and $\mathrm{Sr} / \mathrm{Al}$ are very well and positively correlated. Probably they are concentrated in the same phase, while dissolved $\mathrm{Ca}$ derived from the dissolution of carbonates during hydrothermal leaching may form particles of secondary minerals such as anhydrite or clay minerals (Von Damm et al., 1985). Furthermore, particulate Sr should be incorporated in anhydrite as well. Finally, $\mathrm{Li} / \mathrm{Al}$ and $\mathrm{Si} / \mathrm{Al}$ are found to be correlated positively only in Kephalos vents. The $\mathrm{Fe} /(\mathrm{Fe}+\mathrm{Mn}+\mathrm{Al})$ ratio and especially that of $\mathrm{Al} /(\mathrm{Fe}+\mathrm{Mn}+\mathrm{Al})$ can be used as an indication of hydrothermal versus detrital sediment inputs. Values being below 0.60 is considered as an indication of hydrothermal versus detrital sediment inputs while values below 10 or even 20 are strongly related to submarine hydrothermalism or volcanism (Bostrom et al., 1969; Edmonds and German, 2004). In Kos hydrothermal particles the $\mathrm{Al} /(\mathrm{Fe}+\mathrm{Mn}+\mathrm{Al})$ ratio varied between $0.16-0.62$ and an average 0.29 in Kephalos Bay and from 0.03-0.53 with an average 0.29 in Bros Thermi (Table 2). Furthermore, the fluctuation of $\mathrm{Fe} /(\mathrm{Fe}+\mathrm{Mn}+\mathrm{Al})$ ratio found to be above 0.50 in most samples with only one exception in Bros Thermi and one in Kephalos.

\subsection{Factor analysis}

R-Mode statistical analysis was performed for SPM elemental data using SPSS 18. In Kephalos Bay 
2 factors were account for $73.31 \%$ of total variance and in Bros Thermi 2 factors $87.72 \%$. In Kephalos Bay Factor 1, which described 55.0\% of the total variance, presents high loadings for Mn, $\mathrm{Pb}, \mathrm{Ca}, \mathrm{Ba}, \mathrm{Sr} \mathrm{Li}$ and $\mathrm{Al}$. The second factor consists from $\mathrm{Cu}$ and $\mathrm{Si}$ account for $18.3 \%$ of the total variance. SPM in this site consist mainly of hydrothermal oxides and hydroxides of $\mathrm{Fe}, \mathrm{Mn}$, and $\mathrm{Pb}$ but contains also a lithogenic mixture of $\mathrm{Ca}, \mathrm{Ba}$ and $\mathrm{Sr}$ linked with the limestone substrate and also $\mathrm{Li}-\mathrm{Al}$ fraction which can be attributed to a deeper volcanic rock origin. $\mathrm{Cu}$ and $\mathrm{Si}$ relationship can be attributed to oxidation of $\mathrm{Cu}$ sulphide by exposure to hydrothermal fluids and forming secondary $\mathrm{Cu}-\mathrm{Si}$ mineral such as Chrysocolla (complex hydrated copper aluminum silicate). Further analysis might need to confirm this. In Bros Thermi Factor 1 described $52.6 \%$ of the total variance presenting high loadings in $\mathrm{Fe}, \mathrm{Mn}, \mathrm{Cu}, \mathrm{Pb}, \mathrm{Ca}, \mathrm{Ba}, \mathrm{Al}$ and $\mathrm{Si}$ and moderate loadings for $\mathrm{Sr}$ and $\mathrm{Li}$. The second factor presents high loadings in SPM, Cd, Li and moderate loadings in $\mathrm{Cu}, \mathrm{Pb}, \mathrm{Ca}, \mathrm{Ba}$, $\mathrm{Sr}, \mathrm{Al}$ and $\mathrm{Si}$. The different geochemical groups observed within the data from two sites also agree with other recent research on Bros Thermi local sediments and hydrothermal venting additions (Megalovasilis and Godelitsas, 2015).

Table 1 - Summary results of submarine hydrothermal SPM, Kos Aegean Sea.

\begin{tabular}{|c|c|c|c|c|c|c|c|c|c|c|c|c|c|c|c|c|}
\hline & Gas & Water & G/W & $\mathbf{p H}$ & SPM & $\mathrm{Fe}$ & Mn & $\mathrm{Cu}$ & $\mathbf{P b}$ & Cd & $\mathrm{Ca}$ & $\mathbf{B a}$ & $\mathbf{S r}$ & $\mathbf{L i}$ & Al & $\mathrm{Si}$ \\
\hline $\begin{array}{l}\text { Kephalos } \\
\text { Bay }\end{array}$ & $1 / \mathrm{h}$ & $1 / \mathrm{h}$ & & & $\mathrm{mg} / \mathrm{l}$ & $\mu \mathrm{g} / \mathrm{l}$ & $\mu \mathrm{g} / 1$ & $\mu \mathrm{g} / 1$ & $\mu \mathrm{g} / \mathrm{l}$ & $\mu \mathrm{g} / \mathrm{l}$ & $\mu \mathrm{g} / \mathrm{l}$ & $\mu \mathrm{g} / \mathrm{l}$ & $\mu \mathrm{g} / 1$ & $\mu \mathrm{g} / \mathrm{l}$ & $\mu \mathrm{g} / \mathrm{l}$ & $\mu \mathrm{g} / 1$ \\
\hline $\min$ & 2.00 & 60.00 & 0.030 & 5.50 & 0.93 & 8.7 & 0.14 & 0.01 & 0.05 & 0.001 & 16.89 & 0.16 & 0.12 & 0.01 & 4.83 & 1.23 \\
\hline $\max$ & $\begin{array}{l}126.00 \\
\end{array}$ & 121.50 & $\begin{array}{l}1.300 \\
\end{array}$ & 5.95 & 8.64 & 87.2 & 2.33 & 0.34 & 0.52 & 0.015 & 215.38 & \begin{tabular}{|l|}
1.46 \\
\end{tabular} & 2.07 & \begin{tabular}{|l|l|}
0.28 \\
\end{tabular} & 90.25 & 112.50 \\
\hline geomean & 48.26 & 90.55 & 0.525 & 5.66 & 3.43 & 34.8 & 0.67 & \begin{tabular}{|l|}
0.10 \\
\end{tabular} & 0.17 & 0.002 & 62.05 & \begin{tabular}{|l|}
0.54 \\
\end{tabular} & 0.48 & \begin{tabular}{|l|l|}
0.04 \\
\end{tabular} & 15.46 & 10.20 \\
\hline average & 72.64 & 93.46 & 0.769 & 5.66 & 4.32 & 44.5 & 0.96 & \begin{tabular}{|l|}
0.14 \\
\end{tabular} & 0.21 & 0.004 & 87.57 & \begin{tabular}{|l|}
0.67 \\
\end{tabular} & 0.75 & \begin{tabular}{|l|}
0.08 \\
\end{tabular} & 27.20 & 29.05 \\
\hline stdev & 37.76 & 23.89 & 0.432 & 0.15 & 2.91 & 28.9 & 0.77 & 0.11 & 0.15 & 0.005 & 69.96 & \begin{tabular}{|l|}
0.44 \\
\end{tabular} & \begin{tabular}{|l|}
0.72 \\
\end{tabular} & \begin{tabular}{|l|l|}
0.09 \\
\end{tabular} & 31.23 & 40.29 \\
\hline & & & & & & & & & & & & & & & & \\
\hline \multicolumn{17}{|c|}{ Bros Thermi } \\
\hline $\min$ & 4.50 & 16.50 & 0.180 & 6.09 & 0.21 & 6.5 & 0.05 & 0.10 & 0.08 & 0.001 & 14.58 & \begin{tabular}{|l|}
0.09 \\
\end{tabular} & \begin{tabular}{|l|}
0.13 \\
\end{tabular} & 0.01 & 1.53 & 0.56 \\
\hline $\max$ & 60.00 & 96.00 & 1.140 & 6.53 & 20.94 & \begin{tabular}{|l|}
228.8 \\
\end{tabular} & 2.17 & \begin{tabular}{|l|}
1.01 \\
\end{tabular} & 1.34 & 0.038 & 181.82 & \begin{tabular}{|l|l|}
0.91 \\
\end{tabular} & \begin{tabular}{|l|}
1.19 \\
\end{tabular} & \begin{tabular}{|l|l|}
0.85 \\
\end{tabular} & \begin{tabular}{|l|l|}
191.95 \\
\end{tabular} & 104.77 \\
\hline geomean & 20.62 & 43.52 & 0.474 & 6.23 & 2.89 & 55.6 & 0.43 & \begin{tabular}{|l|}
0.23 \\
\end{tabular} & \begin{tabular}{|l|}
0.37 \\
\end{tabular} & \begin{tabular}{|l|}
0.006 \\
\end{tabular} & 47.11 & 0.26 & \begin{tabular}{|l|}
0.37 \\
\end{tabular} & \begin{tabular}{|l|}
0.09 \\
\end{tabular} & 18.41 & 7.98 \\
\hline average & 24.71 & 47.70 & 0.544 & 6.23 & 6.06 & 80.2 & 0.66 & 0.30 & 0.47 & 0.011 & 62.08 & 0.33 & 0.48 & \begin{tabular}{|l|}
0.23 \\
\end{tabular} & 53.25 & 23.15 \\
\hline stdev & 14.79 & 20.20 & 0.296 & 0.13 & 6.88 & 59.5 & 0.56 & 0.25 & 0.34 & 0.012 & $\begin{array}{ll}47.79 \\
\end{array}$ & \begin{tabular}{|l|}
0.24 \\
\end{tabular} & \begin{tabular}{|l|}
0.36 \\
\end{tabular} & \begin{tabular}{|l|l|}
0.28 \\
\end{tabular} & \begin{tabular}{l|l}
62.58 \\
\end{tabular} & 29.48 \\
\hline
\end{tabular}

Table 2 - Metal/Al ratios of submarine hydrothermal SPM, Kos Aegean sea.

\begin{tabular}{|r|c|c|c|c|c|c|c|c|c|c|c|c|}
\hline & $\mathbf{F e} / \mathbf{A l}$ & $\mathbf{M n} / \mathbf{A l}$ & $\mathbf{C u} / \mathbf{A l}$ & $\mathbf{P b} / \mathbf{A l}$ & $\mathbf{C d} / \mathbf{A l}$ & $\mathbf{C a} / \mathbf{A l}$ & $\mathbf{B a} / \mathbf{A l}$ & $\mathbf{S r} / \mathbf{A l}$ & $\mathbf{L i} / \mathbf{A l}$ & $\mathbf{S i} / \mathbf{A l}$ & $\mathbf{F e} / \mathbf{F e}+\mathbf{M n}+\mathbf{A l}$ & $\mathbf{A l} / \mathbf{F e}+\mathbf{M n}+\mathbf{A l}$ \\
\hline \multicolumn{2}{|c|}{ Kephalos Bay } & & & & & & & & & & & \\
\hline $\min$ & 0.58 & 0.026 & 0.002 & 0.005 & 0.0000 & 2.39 & 0.013 & 0.023 & 0.002 & 0.212 & 0.36 & 0.16 \\
\hline max & 5.03 & 0.090 & 0.030 & 0.029 & 0.0030 & 9.45 & 0.131 & 0.056 & 0.006 & 5.769 & 0.82 & 0.62 \\
\hline geomean & 2.25 & 0.043 & 0.006 & 0.011 & 0.0001 & 4.02 & 0.035 & 0.031 & 0.003 & 0.660 & 0.65 & 0.29 \\
\hline average & 2.66 & 0.048 & 0.012 & 0.013 & 0.0006 & 4.44 & 0.046 & 0.033 & 0.003 & 1.384 & 0.67 & 0.32 \\
\hline stdev & 1.43 & 0.023 & 0.012 & 0.009 & 0.0011 & 2.42 & 0.040 & 0.012 & 0.002 & 2.043 & 0.15 & 0.15 \\
\hline \multicolumn{2}{r|}{} & & & & & & & & & & & \\
\hline Bros Thermi & & & & & & & & & & & & \\
\hline min & 0.88 & 0.006 & 0.002 & 0.004 & 0.0001 & 0.64 & 0.003 & 0.005 & 0.003 & 0.042 & 0.47 & 0.03 \\
\hline max & 38.92 & 0.063 & 0.122 & 0.144 & 0.0202 & 18.43 & 0.087 & 0.122 & 0.012 & 2.916 & 0.97 & 0.53 \\
\hline geomean & 3.02 & 0.023 & 0.013 & 0.020 & 0.0004 & 2.56 & 0.014 & 0.020 & 0.004 & 0.434 & 0.69 & 0.23 \\
\hline average & 5.56 & 0.030 & 0.031 & 0.039 & 0.0018 & 4.39 & 0.026 & 0.035 & 0.005 & 0.698 & 0.71 & 0.29 \\
\hline stdev & 9.16 & 0.019 & 0.042 & 0.044 & 0.0050 & 4.87 & 0.028 & 0.035 & 0.002 & 0.813 & 0.17 & 0.17 \\
\hline
\end{tabular}

\section{Discussion - Conclusions}

Different gas content equilibrium, $\mathrm{pH}$ and redox conditions of hydrothermal fluids together with different rock basement and water source result in various particulate matter types containing diverse crystal forms and aggregates (Chester and Jickells, 2012). The elemental geochemistry of SPM presents some similarities but also differentiations between study areas were observed. Fe particulate correlates well with $\mathrm{Mn}, \mathrm{Cu}$ and $\mathrm{Pb}$ particles suggesting a common sulphide source. Also $\mathrm{Ca}, \mathrm{Ba}$ and $\mathrm{Sr}$ particulate concentrations are well correlated linked with dissolution of carbonate substrate maybe forming secondary minerals such as anhydrite $\mathrm{CaSO}_{4}, \mathrm{BaSO}_{4}$ and $\mathrm{SrSO}_{4}$. Finally the particulate concentrations of $\mathrm{Al}, \mathrm{Si}$ and $\mathrm{Li}$ being also well correlated, forming the "lithogenic" group of hydrothermal particles (Fig. 2). 

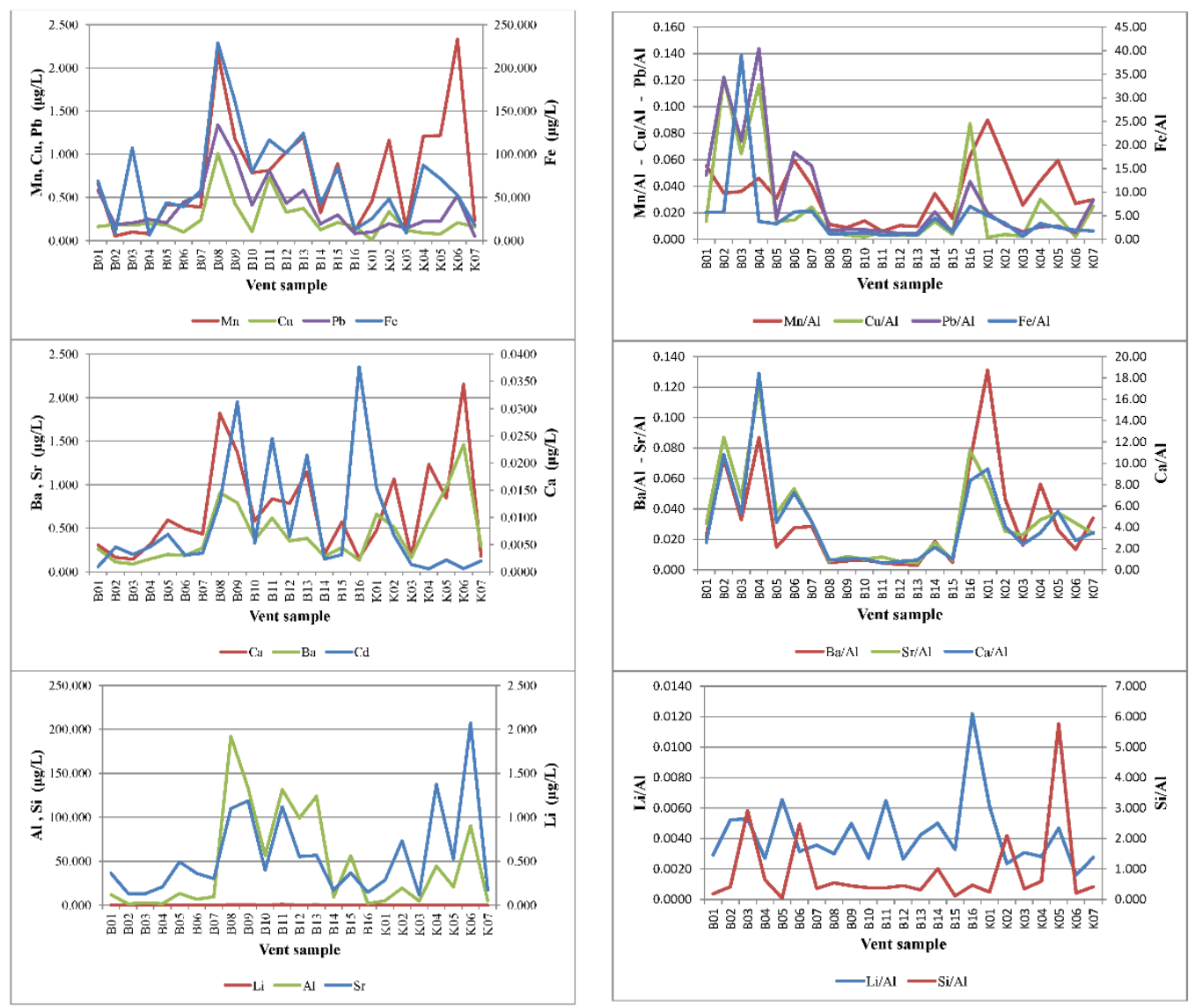

Figure 2 - Elemental concentration variability in hydrothermal SPM, Kos Aegean Sea.

Kephalos Bay hydrothermal site presents higher gas and water flux compared with Bros Thermi but gas/water ratio is similar. Periodicity in sediment temperature caused by tidal and barometric pressure affect pore pressure in sediment and consequently controls flux of nutrients and metals. As a consequence, bacterial mats morphology and expansion around seeps vary with time.(Aliani et al., 2004). The SPM concentration is higher in Bros Thermi than in Kephalos coupled with higher levels of $\mathrm{Mn}, \mathrm{Cu}$ and $\mathrm{Fe}$. Both fields present same levels of concentrations in $\mathrm{Mn}, \mathrm{Si}$ and $\mathrm{Ca}$. Higher concentrations are observed in Bros Thermi for $\mathrm{Fe}, \mathrm{Cu}, \mathrm{Cd}, \mathrm{Li}, \mathrm{Pb}$ and $\mathrm{Al}$, while increased concentrations in $\mathrm{Ba}$ and $\mathrm{Sr}$ found in Kephalos Bay (Fig. 2). Particulate Fe is associated in a different way with specific elements, such as with $\mathrm{Cu}$ on the two hydrothermal areas, presenting no distinct trend in Kephalos while the opposite is observed in Bros Thermi. Furthermore, Fe presents similar positive concentrations trends with $\mathrm{Mn}$ and with $\mathrm{Pb}$ and $\mathrm{Al}$ on both fields. In many environments $\mathrm{Ca}, \mathrm{Ba}$ and $\mathrm{Sr}$ are very well geochemically correlated and coupled because of similarities on their geochemical propertied despite possible different sources and biogenic affiliations. In Kos their concentrations are quite similar in both areas indicating a common carbonate substrate beneath the island, leached by the hydrothermal ascending fluids. A barite $\left(\mathrm{BaSO}_{4}\right)$, source for $\mathrm{Ba}$ is also possible. Lithogenic elements in SPM present different relationships in their concentrations such as between $\mathrm{Si}$ and $\mathrm{Al}$ while they follow similar interrelationships with $\mathrm{Li}$ in both areas studied. Si and $\mathrm{Al}$ in Kephalos only show more distinguishable trend (Megalovasilis, 2015b). There are only a few studies for hydrothermal particulate matter along the Hellenic volcanic arc Comparing with existing literature, Kos submarine hydrothermal SPM levels are below the Milos SPM (Palaeochori Bay) concentrations and similar with other submarine hydrothermal areas in Milos such as Voudia Bay 
and Adamas Bay (Varnavas et al., 2000; Megalovasilis, 2007). Notably particulate Fe is exhibiting high concentrations only in Bros Thermi while Mn particulate is high in both fields and both elemental concentrations are comparable with Milos Palaeochori Bay. In addition, the strong influence of sedimentary substrate is imprinted with the very high levels of particulate Ca being the highest observed along the volcanic arc. Elevated particulate $\mathrm{Sr}$ is also observed in Kos and remarkably high particulate $\mathrm{Al}$ are found in Bros Thermi suggesting strong Al-Silicate mineral assemblages underneath the hydrothermal site. Previous research on sediments deposited near the venting area of Bros Thermi suggested the possible existence of significant metallic sulphide deposits of hydrothermal origin at depth beneath Kos (Megalovasilis and Godelitsas, 2015). It is quite difficult if not impossible to compare fully hydrothermal particulate concentrations of elements in all marine environments such as the shallow vents and hydrothermal fields of open oceans; because of huge differences on sampling procedures and the actual dispersion of plumes in the water column. When scuba diving is involved, sampling results in more condense and isolated hydrothermal fluid component while niskin bottle sampling (or in situ pumping of seawater), over hydrothermal plumes and submarine volcanoes with hydrothermal activity, contains more diluted hydrothermal component altered by the prevailing oceanographic conditions. Summarising, particle chemistry from the submarine vents studied were dominated by $\mathrm{Fe}, \mathrm{Ca}, \mathrm{Si}$ and $\mathrm{Al}$ and strongly enriched in $\mathrm{Mn}, \mathrm{Cu}, \mathrm{Pb}$ and $\mathrm{Ba}$. Data are indicating that hydrothermal vents are major sources for basic metals and trace elements such as $\mathrm{Fe}, \mathrm{Mn}, \mathrm{Cu}, \mathrm{Pb}$ and $\mathrm{Cd}$. The different elemental associations in the two study sites are attributed mainly to the different geologic type of substrate petrology rather than in very different hydrothermal processes prevailing. But because the two study sites presented differences in their $\mathrm{pH}$, gas flux, water flux and gas/water ratio a different hydrothermal reactivity between the two sites is assumed. Particulate matter originating from hydrothermal vents plays important role in local marine sediments geochemistry and it seems is ruled by the geochemistry of the geologic basement and the water-rock interactions taking place beneath in the substrate. Longterm or short-term time series or even periodical sampling of hydrothermal fluids are of prime importance in furthering our understanding on shallow-sea hydrothermal systems and strongly suggested. Furthermore, future investigations should incorporate study of both dissolved and particulate species together with mineralogical analysis and SEM images in order to access the geochemistry of these vents in total.

\section{Acknowledgments}

I want to thank divers P. Tsarpalis, K. Romeos for their excellent work during all the submarine research, Prof. P. Dando and Prof. S. Varnavas for providing the opportunity to collect and perform chemical analyses on samples. Part of this work had been funded by the EU MAST programme, Contract No. MAST2-CT94-0101.

\section{References}

Aliani, S., Meloni, R. and Dando, P.R., 2004. Periodicities in sediment temperature time-series at a marine shallow water hydrothermal vent in Milos Island (Aegean Volcanic arc, Eastern Mediterranean), Journal of Marine Systems, 46(1-4), 109-119.

Bachmann, O., Deering, C.D., Ruprecht, J.S., Huber, C., Skopelitis, A. and Schnyder, C., 2012. Evolution of silicic magmas in the Kos-Nisyros volcanic center, Greece: cycles associated with caldera collapse, Contributions to Mineralogy and Petrology, 163(1), 151-166.

Balopoulos, E.T., Theocharis, A., Kontoyiannis, H., Varnavas, S., Voutsinou-Taliadouri, F., Iona, A., Souvermezoglou, A., Ignatiades, L., Gotsis-Skretas, O. and Pavlidou, A., 1999. Major advances in the oceanography of the southern Aegean Sea-Cretan Straits system (eastern Mediterranean), Progress in Oceanography, 44(1-3), 109-130.

Bostrom, K., Peterson, M.N.A., Joensuu, O. and Fisher, D.E., 1969. Aluminum-poor ferromanganoan sediments on active oceanic ridges, Journal of Geophysical Research, 74(12), 3261-3270. 
Chester, R. and Jickells, T.D., 2012. Marine Geochemistry, 3rd Edition. Wiley-Blackwell.

Dando, P.R., Hughes, J.A., Leahy, Y., Niven, S.J., Taylor, L.J. and Smith, C., 1995. Gas venting rates from submarine hydrothermal areas around the island of Milos, Hellenic Volcanic Arc, Continental Shelf Research, 15(8), 913-929.

Dando, P.R., Thomm, M., Arab, H., Brehmer, M., Hooper, L.E., Jochimsen, B., Schlesner, H., Stohr, R., Miquel, J.C. and Fowler, S.W., 1998. Microbiology of shallow hydrothermal sites off Palaeochori Bay, Milos (Hellenic Volcanic Arc), Cahiers de Biologie Marine, 39(3-4), 369-372.

Dando, P. R., Aliani, S., Arab, H., Bianchi, C.N., Brehmer, M., Cocito, S., Fowler, S.W., Gundersen, J., Hooper, L.E., Kolbl, R., Kuever, J., Linke, P., Makropoulos, K.C., Meloni, R., Miquel, J.C., Morri, C., Muller, S., Robinson, C., Schlesner, H., Sievert, S., Stohr, R., Stuben, D., Thomm, M., Varnavas, S.P. and Ziebis, W., 2000. Hydrothermal studies in the aegean sea, Physics and Chemistry of the Earth, Part B: Hydrology, Oceans and Atmosphere, 25(1), 1-8.

Edmonds, H.N. and German, C.R., 2004. Particle geochemistry in the Rainbow hydrothermal plume, Mid-Atlantic Ridge, Geochimica et Cosmochimica Acta, 68(4), 759-772.

Godelitsas, A., Price, R.E. Pichler, T., Amend, J., Gamaletsos, P. and Goettlicher, J., 2015. Amorphous As-sulfide precipitates from the shallow-water hydrothermal vents off Milos Island (Greece), Marine Chemistry, 177(5), 687-696.

Hatzivasileiou, V., 2013. History of Island of Kos Ancient, Medieval and Modern, Municipality of Kos, Kos Greece.

Humphris, S.E., Zierenberg, R.A., Mullineaux, L.S. and Thomson, R.E., 1995. Seafloor Hydrothermal Systems:Physical, Chemical, Biological, and Geological Interactions, AGU Monograph 91 American Geophysical Union, Willey, Washington, DC. 466.

Karageorgis, A.P. and Anagnostou, C.L., 2001. Particulate matter spatial-temporal distribution and associated surface sediment properties: Thermaikos Gulf and Sporades Basin, NW Aegean Sea, Continental Shelf Research, 21, 2141-2153.

Lagios, E., Galanopoulos, D., Hobbs, B.A. and Dawes, G.J.K., 1998. Two-dimensional magnetotelluric modelling of the Kos Island geothermal region (Greece), Tectonophysics, 287(1-4), 157-172.

Landing, W.M. and Lewis, B.L., 1991. Collection, processing and analysis of marine particulate and colloidal material for transition metals. In: Marine Particles: Analysis and Characterization, Spencer, D. and Hurd, D., eds., Geophys. Monog. AGU, 63, 263-272.

Loring, D.H. and Rantala, R.T.T., 1992. Manual for the geochemical analyses of marine sediments and suspended particulate matter, Earth Sciences Reviews, 32, 235-283.

Lupton, J.E., 1995. Hydrothermal plumes: near and far fields. In: Humphries, S.E., Zierenberg, R.A., Mullineaux, L.S., et al., eds., Seafloor Hydrothermal Systems: Physical, Chemical, Biological and Geological Interactions, American Geophysical Union 91, Washington D.C., 317-346.

Megalovasilis, P., 2007. Geochemical research on sediments and waters in submarine hydrothermal areas along the Aegean Volcanic Arc (in Greek with English Abstract) Ph.D, Thesis, Athens, National and Kapodistrian University of Athens.

Megalovasilis, P., 2014. Partition geochemistry of hydrothermal precipitates from submarine hydrothermal fields in the Hellenic Volcanic Island Arc, Geochemistry International, 52(11), 992-1010.

Megalovasilis, P. and Godelitsas, A., 2015. Hydrothermal influence on nearshore sediments of Kos Island, Aegean Sea, Geo-Marine Letters, 35(2), 77-89.

Megalovasilis, P., 2015a. Evaluation of hydrothermal SPM inputs in Aegean Sea. In: 11th Panhellenic Symposium on Oceanography and Fisheries, «Aquatic Horizons: Challenges \& Perspectives», Hellenic Centre for Marine Research, 1, 365-368.

Megalovasilis, P., 2015b. Hydrothermal fluid particle geochemistry of submarine vents in Kos Island, Aegean Sea East Mediterranean, Journal of Marine Systems, Submitted: 1-25.

Minissale, A., Duchi, V., Kolios, N., Nocenti, M. and Verrucchi, C., 1997. Chemical patterns of thermal aquifers in the volcanic islands of the Aegean Arc, Greece, Geothermics, 26(4), 501-518.

Nomikou, P., Papanikolaou, D., Alexandri, M., Sakellariou, D. and Rousakis, G., 2013. Submarine volcanoes along the Aegean volcanic arc, Tectonophysics, 597-598(0), 123-146. 
Papanikolaou, D. and Lekkas, E., 1990. Miocene tectonism in Kos, Dodecanese islands, IESCA Abstract, 179-180.

Parson, L., Walker, C.L. and Dixon, D.R.E., 1995. Hydrothermal vents and processes. Geological Society London.

Pe-Piper, G., Piper, D.J.W. and Perissoratis, C., 2005. Neotectonics and the Kos Plateau Tuff eruption of $161 \mathrm{ka}$, South Aegean arc, Journal of Volcanology and Geothermal Research, 139(3-4), 315-338.

Pichon, X.L. and Angelier, J., 1979. The Hellenic arc and trench system: a key to the neotectonic evolution of the eastern mediterranean area, Tectonophysics, 60(1-2), 1-42.

Price, R.E., Savov, I., Planer-Friedrich, B., Bühringa, S.I., Amendb, J. and Pichlera, T., 2013. Processes influencing extreme As enrichment in shallow-sea hydrothermal fluids of Milos Island, Greece, Chemical Geology, 348, 15-26.

Royden, L.H. and Papanikolaou, D.J., 2011. Slab segmentation and late Cenozoic disruption of the Hellenic arc, Geochemistry, Geophysics, Geosystems, 12(3), 1-24.

Ruffa, G.L., Panichi, C., Kavouridis, T. et al., 1999. Isotope and chemical assessment of geothermal potential of Kos Island, Greece, Geothermics, 28(2), 205-217.

Varnavas, S., Megalovasilis, P., Panagiotaras, D. et al., 1998. Compositional and morphological characterisation of particulate matter in hydrothermal fields of the Hellenic Volcanic arc, In: XXIII General Assembly of European Geophysical Society (EGS), Part II Hydrology, Oceans \& Atmospere, European Geophysical Society, Annales Geophysicae, Supplement II to Volume 16, 16, C 744.

Varnavas, S., Panagiotaras, D. and Megalovasilis, P., 1998. Chemical characteristics of a submarine hydrothermal system offshore Kos island, on the Hellenic Volcanic Arc. Rapports et ProcèsVerbaux de la Commission Internationale Pour L'Exploration Scientifique de la mer Mediterranee, 35th CIESM Congress, 35(1), 104-105.

Varnavas, S.P. and Cronan, D.S., 1991. Hydrothermal metallogenic processes off the islands of Nisiros and Kos in the Hellenic Volcanic Arc, Marine Geology, 99(1-2), 109-133.

Varnavas, S.P., Panagiotaras, D. and Megalovasilis, P. et al., 2000. Compositional characterization of suspended particulate matter in hellenic volcanic arc hydrothermal centres, Physics and Chemistry of the Earth, Part B: Hydrology, Oceans and Atmosphere, 25(1), 9-18.

Von Damm, K.L., Edmond, J.M., Measures, C.I., et al., 1985. Chemistry of submarine hydrothermal solutions at Guaymas Basin, Gulf of California, Geochim. Cosmochim. Acta, 49, 2221-2237.

Von Damm, K.L., 1990. SeaSoor hydrothermal activity: black smoker chemistry and chimneys, Annual Review of Earth and Planetary Science, 18, 173-204.

Von Damm, K.L., 2001. Chemistry of hydrothermal vent fluids. In: Steele, J.H., ed., Encyclopedia of Ocean Sciences, Academic Press Oxford, 3, Cambridge, Massachusetts USA, 1246-1253.

Whittield, M. and Turner, R.D., 1987. The role of particles in regulating the composition of sea water. In: Stumm, W., ed., Aquatic Surface Chemistry: Chemical Processes at the Particle Water Interface, John Wiley N.Y., New York, 457-493.

Yücel, M., Sievert, S.M., Vetriani, C. et al., 2013. Eco-geochemical dynamics of a shallow-water hydrothermal vent system at Milos Island, Aegean Sea (Eastern Mediterranean), Chemical Geology, 356(0), 11-20. 